Review Article

\title{
The Need for Laparoscopic Ovarian Transposition in Young Patients with Cervical Cancer Undergoing Radiotherapy
}

\author{
Hariyono Winarto, Eva Febia, Gatot Purwoto, and Laila Nuranna \\ Gynecologic Oncology Division, Department of OBGYN, Faculty of Medicine, University of Indonesia, \\ Gedung A lt. 3, Medical Staff Wing Dr. Cipto Mangunkusumo Hospital, Jakarta 10430, Indonesia
}

Correspondence should be addressed to Hariyono Winarto; hariyonow@gmail.com

Received 23 May 2013; Accepted 10 October 2013

Academic Editor: Dimitrios Loutradis

Copyright (C) 2013 Hariyono Winarto et al. This is an open access article distributed under the Creative Commons Attribution License, which permits unrestricted use, distribution, and reproduction in any medium, provided the original work is properly cited.

\begin{abstract}
Maintaining the quality of life by preserving ovarian function in premenopausal patients with cervical cancer undergoing radiation is crucial. This can be accomplished with a simple and safe laparoscopic ovarian transposition procedure. This procedure aims to move the ovary out of the irradiation field, protecting it from direct radiation and irreversible damage and preserving its function. However, this procedure is often forgotten and seldom offered to patients. This review aims to lay stress on and reconsider the importance of laparoscopic ovarian transposition as a simple, safe, and extremely useful procedure. The biological effects of radiation are described briefly and several studies are evaluated, which reveal that this procedure has more benefits than risks.
\end{abstract}

\section{Introduction}

Cervical cancer is one of the commonest malignancies in Indonesian women. The annual incidence is 9.25 per 100000 population. Due to advances in screening and treatment, patients with cervical cancer are being diagnosed at a younger age and earlier stage of the disease. Approximately half the patients are premenopausal and under 45 years old. Radiotherapy, which constitutes almost $80 \%$ of all cancer treatment modalities, causes irreversible ovarian damage and leads to premature menopause, which affects the quality of life. Young women with cervical cancer who are irradiated often have to suffer the long-term consequences of ovarian failure. In addition to curing those patients, maintaining their quality of life is important for a gynecologist. Improved quality of life is significantly associated with improved survival in patients with cervical cancer [1-8].

A simple procedure for preventing radiotherapy-induced ovarian damage is laparoscopic ovarian transposition. This procedure has not been implemented widely even though many studies have revealed its benefits and efficacy. This review assesses the use of ovarian transposition as an effective method for preserving ovarian function in young patients with cervical cancer undergoing radiotherapy and compares the benefits of ovarian transposition performed via laparoscopy and via laparotomy [9-13].

\section{The Biological Effect of Radiotherapy and the Fate of Retained versus Transposed Ovaries}

Radiotherapy aims to deliver a precisely measured dose of radiation to a defined tumor volume with minimum possible damage to the surrounding normal tissue. Ionizing radiotherapy interacts with DNA. The initial DNA damage leads to a cascade of biologic events that cause lethality when the cells attempt to divide (mitotic death) or programmed cell death (apoptosis), as well as sublethal damage that leads to aging, malformations, and malfunction (Figure 1) [14, 15].

The human ovary contains a finite number of ovarian follicles, which are vulnerable to DNA damage from radiotherapy. The degree and persistence of ovarian damage and the suppression of its function are related to the patient's age and the dose of radiation delivered to the ovaries. After the ovaries are exposed to ionizing radiation, if the dose 


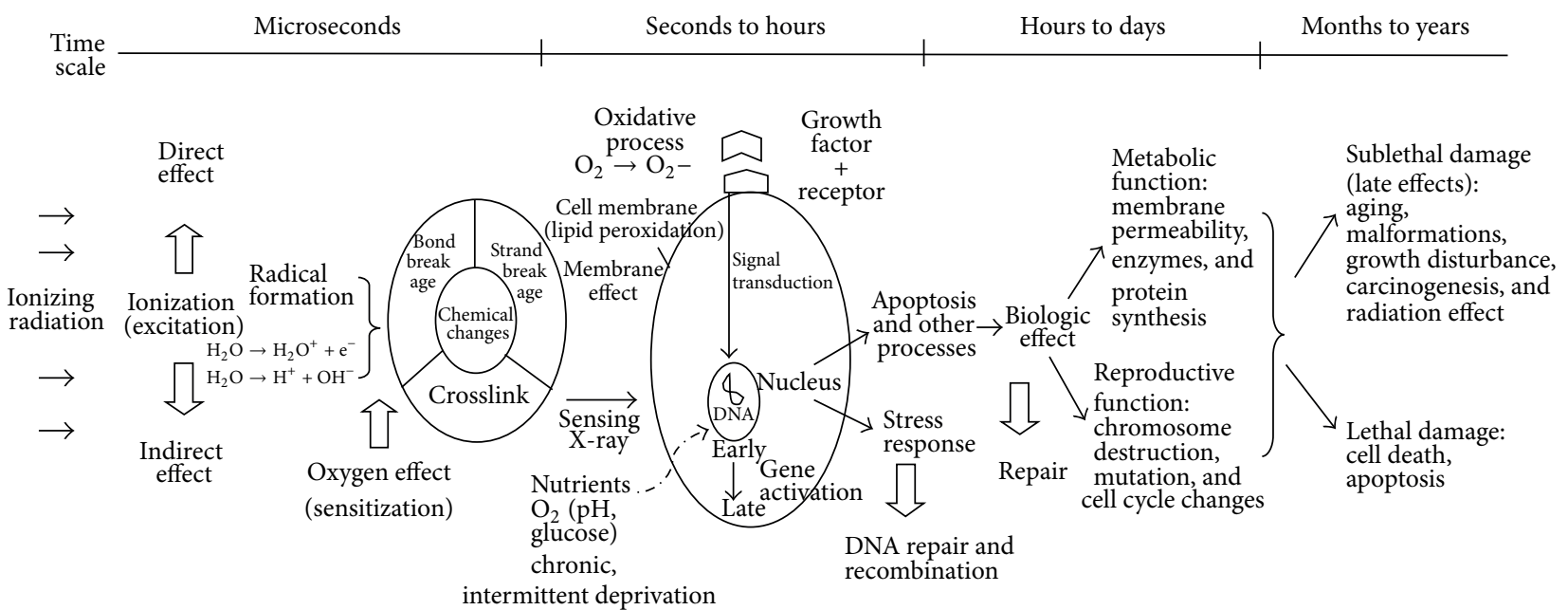

FIGURE 1: Fate of irradiated cell. Schematic representation of the various processes that take place after cell irradiation [14-16].

of radiation exceeds the lethal dose, most of the primordial follicles and granulose cells will die in microseconds. Some of those follicles and cells experience sublethal damage, leading to accelerated functional failure. Only a small number would escape the damage, undergo repair, and still have their function. Pyknotic granulose cells would be seen soon after irradiation, and with sufficient destruction of the granulose cells, the follicle would become atrophic. There would be a loss of the cortical stromal cells, and in time, the cortical volume would be replaced by collagen $[6,12,13,15,17,18]$.

The cutoff dose for radiation-induced ovarian failure is around $8-20 \mathrm{~Gy}$. A dose $>8 \mathrm{~Gy}$ causes permanent ovarian damage in almost all patients older than 40 years. A dose $>20$ Gy causes permanent sterility in patients of any age, with complete or near complete disappearance of the primordial follicles. Radiotherapy used in cervical cancer treatment consists of high-dose external radiotherapy and brachytherapy. The dose of radiotherapy for cervical cancer should be lethal to the cervical tumor tissue. It ranges from $45 \mathrm{~Gy}$ to as high as $90 \mathrm{~Gy}$, exceeding the lethal dose for ovarian follicles, and results in permanent damage and loss of ovarian functions in all patients of any age, unless some interventions are applied. Transposing the ovaries is a method of minimizing ovarian follicle exposure to radiation $[12,13,19]$.

\section{Rationale, Benefits, Complications, and Indications of Ovarian Transposition}

Transposing the ovary away from the radiation field can be done surgically at the time of radical hysterectomy or before radiotherapy. In patients with cervical cancer, the ovaries are transposed or moved to the lateral side of the abdomen above the pelvic inlet to place them far enough from external pelvic radiation exposure or brachytherapy. If the ovaries are transposed laterally, about $3 \mathrm{~cm}$ above the pelvic inlet, they will receive only $1 \%-10 \%$ of the total radiotherapy dose. If the total radiotherapy dose is $45 \mathrm{~Gy}$, then the dose received by the transposed ovaries is only $0.45-4.5 \mathrm{~Gy}$, whereas the retained ovaries could receive $50 \%-70 \%$ of the total dose, which is 20-32 Gy [13, 20-24] (Figure 2).

Successfully preserving ovarian function depends on the distance between the transposed ovaries and the edge of the radiation field. Therefore, the ovaries should be transposed as laterally and as cranially as possible from the pelvic brim. However, attention should be paid to avoid torsion and extension of the ovarian vessels, which may reduce blood supply to the ovaries $[26,27]$.

Lateral ovarian transposition can be performed towards the subcutaneous tissue of the flank or the paracolic gutter. However, attaching the ovary to the flank produces more pain complaints than lateral transposition of the ovaries into the paracolic gutter, which is more widely accepted and results in minimal complications (Table 1). Lateral ovarian transposition to the paracolic gutter lateral to the ascending or descending colon is considered a simple standard procedure and can be done laparoscopically [23, 25, 28-32].

Studies on lateral ovarian transposition show that it is $44 \%-85 \%$ effective in preserving ovarian function and that complications such as symptomatic ovarian cyst formation range from $0 \%$ to $27 \%$. Symptomatic cyst formation occurs more frequently after lateral ovarian transposition to the subcutaneous adipose tissue $(20 \%-27 \%)$ than after lateral ovarian transposition to the paracolic gutter. Ovarian metastasis is rare (0\%-1.2\%) but is reported. A case of abdominal trocar insertion metastasis after laparoscopic lateral ovarian transposition in a patient with cervical cancer, adenocarcinoma stage IIB was reported. The incidence of trocar insertion metastasis is $<1 \%$. As lateral ovarian transposition to the paracolic gutter is a simple and safe procedure for preserving ovarian function, its benefits outweighs the risks of complications [23-25, 28-35] (Table 1).

Lateral ovarian transposition is indicated in young patients with cervical cancer after radical hysterectomy, after neoadjuvant chemotherapy, before radiotherapy, or before concurrent chemoradiotherapy. Some studies showed that the addition of cisplatin in a low dose of $50 \mathrm{mg} / \mathrm{m}^{2}$, used in 


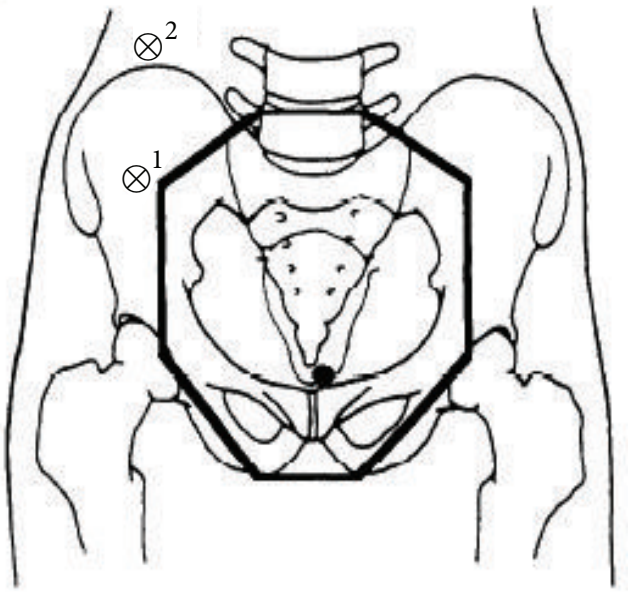

(a)

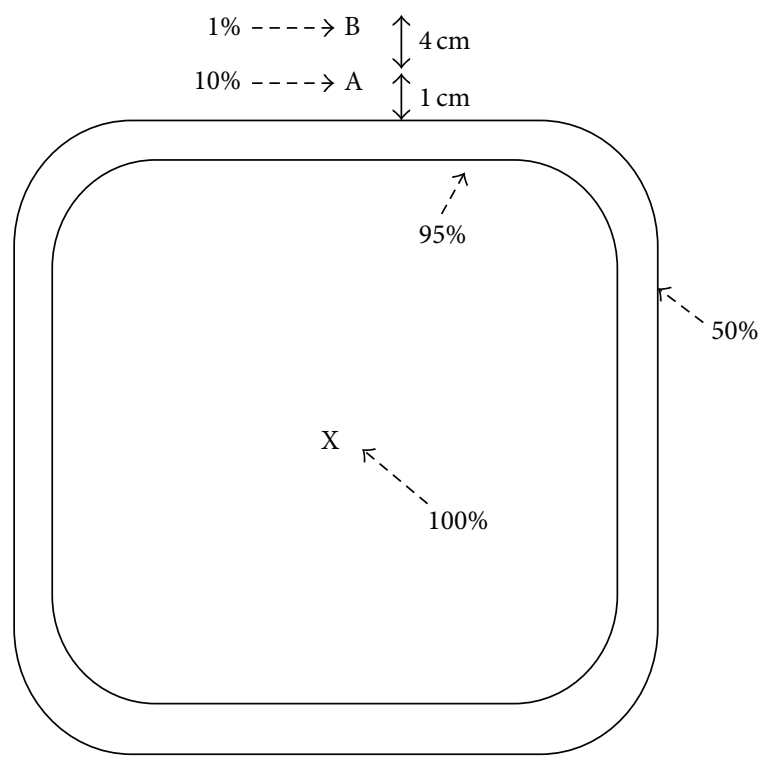

(b)

FIGURE 2: (a) Diagram showing the (AP-PA) whole pelvic radiation therapy field relative to the position of the transposed ovary. Position 1 represents the suboptimal placement of the ovary; position 2 represents the optimal placement of the ovary in terms of maintaining ovarian function. (b) Diagram of a dose distribution. The dose at point A is $10 \%$ of the dose at the center of the field (point X, 100\%). The dose at point $\mathrm{B}$ is $1 \%$ of the dose at point $\mathrm{X}$. Therefore, if the prescribed dose was $45 \mathrm{~Gy}$, the dose is $4.5 \mathrm{~Gy}$ at point $\mathrm{A}$ and $0.45 \mathrm{~Gy}$ at point $\mathrm{B}$ [13, 25].

neoadjuvant chemotherapy or concurrent chemoradiotherapy, did not significantly alter ovarian function. However, adding cisplatin concurrently as radiotherapy functioned as a radiosensitizer and was proven to have better results in some studies. The addition of vincristine and bleomycin in low doses of $1 \mathrm{mg} / \mathrm{m}^{2}$ and $25 \mathrm{mg} / \mathrm{m}^{2}$, respectively, as neoadjuvant chemotherapy did not alter ovarian function either. Lateral ovarian transposition is still used in young patients with cervical cancer after they receive chemotherapeutic agents such as cisplatin, vincristine, and bleomycin in low doses as used in neoadjuvant chemotherapy or concurrent chemoradiotherapy [24, 25, 33, 36-42].

\section{Uterine Transplantation and Surrogacy}

Besides maintaining ovarian function, ovarian transposition can be used in women who wish to maintain their fertility and reproductive function. For patients with cervical cancer who have undergone radiotherapy that extended to the uterus, and/or hysterectomy, uterine transplantation and surrogacy after ovarian transposition are alternatives. However, uterine transplantation has succeeded only in the animal research setting, and only one failed attempt of human uterus transplantation has been reported. Moreover, uterus transplantation and surrogacy are still under ethical debate concerning both the recipient and the donor's reproductive rights [43-46].

\section{Laparoscopy versus Laparotomy Unilateral Ovarian Transposition}

Lateral ovarian transposition is a simple procedure that can be performed laparoscopically. Laparoscopic ovarian transposition is superior to laparotomy. Many studies showed that laparoscopic ovarian transposition, like other minimally invasive procedures, produced less risk of adhesion, inflammation, and shortened length of hospital stay in addition to reduced recovery time, resulting in fewer delays in radiotherapy compared with laparotomy. Since laparotomy necessitates a longer postoperative recovery time, it significantly delays radiotherapy. In some cases, the transposed ovary has returned to the previous position due to the delay, resulting in failure to preserve the ovaries $[9,10,33]$.

Laparoscopic ovarian transposition can be performed in a day and the patient is sent for radiotherapy. The minimal postoperative wound will not affect mobility and functional activity, as well as quality of life in cervical cancer patients. Studies showed that the risk of adhesion and cyst formation was less with laparoscopic ovarian transposition compared with laparotomy $[9,10,28,29,33,34]$.

Laparoscopic ovarian transposition can be performed on either ovary. Studies show that steroid hormone production from only one ovary is enough to prevent ovarian function failure. Clough et al. [30] and Giacalone et al. [47] showed that unilateral right ovarian transposition effectively preserves ovarian function in $85 \%$ of subjects. Additionally, unilateral ovarian transposition of the right ovary to the paracolic gutter, as high as the subhepatic region, is technically easier, resulting in fewer complications.

It is important to measure ovarian reserve in patients with cervical cancer aged 41-49 years and in those who have received neoadjuvant chemotherapy before laparoscopic ovarian transposition. To test the ovarian reserve, the menstruation cycle should be assessed and levels of the follicle stimulating hormone (FSH), estradiol, and anti-Müllerian hormone $(\mathrm{AMH})$ should be measured. The $\mathrm{AMH}$ has an 
TABLE 1: Studies reporting the outcome of lateral ovarian transposition in patients with cervical cancer.

\begin{tabular}{|c|c|c|c|c|c|}
\hline Author & Procedure & $\begin{array}{l}\text { Number of } \\
\text { subjects }\end{array}$ & $\begin{array}{l}\text { Position of } \\
\text { transposed } \\
\text { ovary/ovaries }\end{array}$ & Therapy & Outcome \\
\hline Feeney et al. [29] & $\begin{array}{l}\text { Lateral ovarian } \\
\text { transposition } \\
\text { following } \\
\text { hysterectomy }\end{array}$ & 28 & $\begin{array}{l}\text { To the paracolic } \\
\text { gutter }\end{array}$ & $\mathrm{RT} / \mathrm{RH}+\mathrm{RT}$ & $\begin{array}{l}\text { Ovarian preservation was } \\
\text { achieved in } 14 / 28(50 \%) \text { patients }\end{array}$ \\
\hline Fujiwara et al. [28] & $\begin{array}{l}\text { Subcutaneous } \\
\text { ovarian } \\
\text { transposition } \\
\text { following } \\
\text { hysterectomy }\end{array}$ & 27 & $\begin{array}{l}\text { To the fascia of the } \\
\text { abdominal tissue }\end{array}$ & $\mathrm{RT}+\mathrm{RH}$ & $\begin{array}{l}\text { Only } 12 \text { patients ( } 44 \%) \text { had } \\
\text { normal ovarian function }\end{array}$ \\
\hline $\begin{array}{l}\text { Anderson et al. } \\
{[23]}\end{array}$ & $\begin{array}{l}\text { Ovarian } \\
\text { transposition }\end{array}$ & 82 & $\begin{array}{l}\text { Sutured to the } \\
\text { posterior } \\
\text { peritoneum, above } \\
\text { the pelvic brim at the } \\
\text { level of the lower pole } \\
\text { of the kidney }\end{array}$ & RT & $\begin{array}{l}\text { Ovarian preservation was } \\
\text { achieved in } 53 \% \text { of subjects. } \\
\text { Painful ovarian cyst occurred in } \\
20 \% \text { of cases. There was one case } \\
\text { of ovarian metastasis }(1.2 \%)\end{array}$ \\
\hline Huang et al. [24] & $\begin{array}{l}\text { Laparoscopic } \\
\text { bilateral ovarian } \\
\text { transposition }\end{array}$ & $\begin{array}{l}14(<45 \text { years } \\
\text { old })\end{array}$ & $\begin{array}{l}\text { To a high } \\
\text { anterolateral } \\
\text { position, } 3-4 \mathrm{~cm} \\
\text { above the umbilical } \\
\text { line }\end{array}$ & $\begin{array}{c}\mathrm{CCRT} / \mathrm{RT} / \mathrm{RH}+ \\
\mathrm{RT} / \mathrm{NCT}+\mathrm{RH}+\mathrm{RT}\end{array}$ & $\begin{array}{l}\text { No intraoperative or } \\
\text { postoperative complications } \\
\text { occurred. No metastasis was } \\
\text { observed. All patients tolerated } \\
\text { the procedure. Seven of the } 14 \\
\text { patients ( } 50 \%) \text { developed } \\
\text { ovarian failure, shown by the } \\
\text { elevation of FSH level }\end{array}$ \\
\hline Morice et al. [31] & $\begin{array}{l}\text { Bilateral ovarian } \\
\text { transposition }\end{array}$ & $\begin{array}{l}107(21-42 \text { years } \\
\text { old) }\end{array}$ & $\begin{array}{l}\text { To the paracolic } \\
\text { gutter (laparotomy, } \\
102 \text { cases; } \\
\text { laparoscopy, } 5 \text { cases) }\end{array}$ & $\mathrm{RT} / \mathrm{RH}+\mathrm{RT}$ & $\begin{array}{l}\text { One case }(1 \%) \text { with ovarian } \\
\text { metastasis. No other } \\
\text { postoperative complications } \\
\text { occurred. Ovarian function } \\
\text { preservation was achieved in } \\
83 \% \text { of patients }\end{array}$ \\
\hline Morice et al. [33] & $\begin{array}{l}\text { Bilateral ovarian } \\
\text { transposition }\end{array}$ & 24 & $\begin{array}{l}\text { To the paracolic } \\
\text { gutter (laparoscopy) }\end{array}$ & $\begin{array}{c}\mathrm{RT} / \mathrm{RH}+\mathrm{RT} / \mathrm{NCT}+ \\
\mathrm{RT}+\mathrm{RH}\end{array}$ & $\begin{array}{l}\text { Ovarian preservation was } \\
\text { achieved in } 79 \% \text { patients; three } \\
\text { pregnancies were obtained }\end{array}$ \\
\hline $\begin{array}{l}\text { Chambers et al. } \\
\text { [25] }\end{array}$ & $\begin{array}{l}\text { Lateral ovarian } \\
\text { transposition } \\
\text { (by laparotomy) }\end{array}$ & 34 & $\begin{array}{l}\text { Below and above the } \\
\text { iliac crest }\end{array}$ & $\mathrm{RT} / \mathrm{RH}+\mathrm{RT} / \mathrm{CCRT}$ & $\begin{array}{l}\text { Ovarian preservation was } \\
\text { achieved in } 71 \% \text {. Symptomatic } \\
\text { ovarian cyst occurred in } 18 \% \text { of } \\
\text { cases }\end{array}$ \\
\hline Clough et al. [30] & $\begin{array}{l}\text { Laparoscopic } \\
\text { unilateral (right) } \\
\text { ovarian } \\
\text { transposition }\end{array}$ & 20 & $\begin{array}{l}\text { To the paracolic } \\
\text { gutter }\end{array}$ & RT & $\begin{array}{l}\text { There were }(18 / 20 ; 85.3 \%) \text { cases } \\
\text { with normal ovarian function. } \\
\text { No postoperative complication } \\
\text { was observed }\end{array}$ \\
\hline $\begin{array}{l}\text { van Eijkeren et al. } \\
{[34]}\end{array}$ & $\begin{array}{l}\text { Lateral ovarian } \\
\text { transposition } \\
\text { following } \\
\text { hysterectomy }\end{array}$ & 18 & $\begin{array}{l}\text { To the abdominal } \\
\text { sidewall at the level } \\
\text { of the lowest rib }\end{array}$ & RT & $\begin{array}{l}\text { Ovarian preservation was } \\
\text { achieved in } 13 / 18(72 \%) \text { patients }\end{array}$ \\
\hline
\end{tabular}

CCRT: concurrent chemotherapy radiotherapy (adding cisplatin as radio sensitizer with a dose of $50 \mathrm{mg} / \mathrm{m}^{2}$ weekly for 6 courses); RT: radiotherapy; RH: radical hysterectomy; NCT: neoadjuvant chemotherapy (combined cisplatin $50 \mathrm{mg} / \mathrm{m}^{2}$, vincristine $1 \mathrm{mg} / \mathrm{m}^{2}$, and bleomycin $25 \mathrm{mg} / \mathrm{m}^{2}$ in an interval of 10 days, 3 courses in total).

added value since its level is independent of the menstrual cycle, so its assessment can be used in patients who have undergone radical hysterectomy or experienced acute amenorrhea due to neoadjuvant chemotherapy. In some studies, the cutoff value of the $\mathrm{AMH}$ indicating good ovarian reserve varied, such as $\geq 0.3 \mathrm{ng} / \mathrm{mL}, \geq 0.5 \mathrm{ng} / \mathrm{mL}$, and $\geq 1.4$ ng/mL [48-50].

\section{Conclusion}

Laparoscopic ovarian transposition is a simple, safe, effective, but often forgotten, procedure for young premenopausal patients with cervical cancer who are undergoing radiotherapy. We believe this procedure should be offered to all young premenopausal patients with cervical cancer undergoing 
radiotherapy to preserve their ovarian function. However, further studies to evaluate the efficacy of laparoscopic ovarian transposition in our center are still needed.

\section{Conflict of Interests}

No potential conflict of interests relevant to this paper was reported.

\section{References}

[1] M. E. Randall, H. Michael, J. V. Morken, and F. Stehman, "Uterine cervix," in Principles and Practice of Gynecologic Oncology, W. J. Hoskins, C. Perez, R. C. Young, R. R. Barakat, M. Markman, and M. E. Randall, Eds., pp. 743-822, Lippincott Williams \& Wilkins, Philadelphia, Pa, USA, 4th edition, 2005.

[2] X. Castlellsague, S. de Sanjose, Aguado et al., "HPV and cervical cancer in the world 2007 report," Vaccine, vol. 25, supplement 3, pp. C1-C26, 2007.

[3] M. F. Aziz, "Gynecological cancer in Indonesia," Journal of Gynecologic Oncology, vol. 20, no. 1, pp. 8-10, 2009.

[4] M. C. Schellekens, A. Dijkman, M. F. Aziz et al., "Prevalence of single and multiple HPV types in cervical carcinomas in Jakarta, Indonesia," Gynecologic Oncology, vol. 93, no. 1, pp. 49-53, 2004.

[5] V. Kesic, "Management of cervical cancer," European Journal of Surgical Oncology, vol. 32, no. 8, pp. 832-837, 2006.

[6] J. S. Stroud, D. Mutch, J. Rader, M. Powell, P. H. Thaker, and P. W. Grigsby, "Effects of cancer treatment on ovarian function," Fertility and Sterility, vol. 92, no. 2, pp. 417-427, 2009.

[7] I. J. Korfage, M. Essink-Bot, F. Mols, L. van de Poll-Franse, R. Kruitwagen, and M. van Ballegooijen, "Health-related quality of life in cervical cancer survivors: a population-based survey," International Journal of Radiation Oncology Biology Physics, vol. 73, no. 5, pp. 1501-1509, 2009.

[8] M. Wahidin, R. Noviani, S. Hermawan, V. Andriani, A. Ardian, and H. Djarir, "Population-based cancer registration in Indonesia," Asian Pacific Journal of Cancer Prevention, vol. 13, no. 4, pp. 1709-1710, 2012.

[9] M. D. Chen, G. A. Teigen, H. T. Reynolds, P. R. Johnson, and J. M. Fowler, "Laparoscopy versus laparotomy: an evaluation of adhesion formation after pelvic and paraaortic lymphadenectomy in a porcine model," The American Journal of Obstetrics and Gynecology, vol. 178, no. 3, pp. 499-503, 1998.

[10] M. Bisharah and T. Tulandi, "Laparoscopic preservation of ovarian function: an underused procedure," The American Journal of Obstetrics and Gynecology, vol. 188, no. 2, pp. 367-370, 2003.

[11] K. T. Ashing-Giwa, J. W. Lim, and J. Tang, "Surviving cervical cancer: does health-related quality of life influence survival?" Gynecologic Oncology, vol. 118, no. 1, pp. 35-42, 2010.

[12] T. Falcone, M. Attaran, M. A. Bedaiwy, and J. M. Goldberg, "Ovarian function preservation in the cancer patient," Fertility and Sterility, vol. 81, no. 2, pp. 243-257, 2004.

[13] L. Barbera, "Effects of pelvic radiation therapy on fertility," CME Journal of Gynecologic Oncology, vol. 8, no. 2, pp. 101-106, 2003.

[14] S. Falk, "Principles of cancer treatment by radiotherapy," Surgery, vol. 27, no. 4, pp. 169-172, 2009.

[15] C. Perez, J. Purdy, Z. Li, and E. Hall, "Biologic and physical aspects of radiation oncology," in Principles and Practice of Gynecologic Oncology, W. Hoskins, C. Perez, R. Young, R.
Barakat, M. Markman, and M. Mandall, Eds., pp. 375-459, Lippincott Williams \& Wilkins, Philadelphia, Pa, USA, 4th edition, 2005.

[16] J. Yarnold, "Molecular aspects of cellular responses to radiotherapy," Radiotherapy and Oncology, vol. 44, no. 1, pp. 1-7, 1997.

[17] A. L. Presti, G. Ruvolo, R. A. Gancitano, and E. Cittadini, "Ovarian function following radiation and chemotherapy for cancer," European Journal of Obstetrics Gynecology and Reproductive Biology, vol. 113, pp. S33-S40, 2004.

[18] S. S. Kim, "Fertility preservation in female cancer patients: current developments and future directions," Fertility and Sterility, vol. 85, no. 1, pp. 1-11, 2006.

[19] K. Okamoto, N. Sakuragi, and S. Fujimoto, "Ovarian function and survival of patients with cervical carcinoma treated with radical hysterectomy and ovarian transposition," in The Ovary, P. Leung and E. Adashi, Eds., pp. 559-567, Elsevier, New York, NY, USA, 2nd edition, 2004

[20] T. Maltaris, R. Seufert, F. Fischl et al., "The effect of cancer treatment on female fertility and strategies for preserving fertility," European Journal of Obstetrics Gynecology and Reproductive Biology, vol. 130, no. 2, pp. 148-155, 2007.

[21] J. D. Mitchell, C. Hitchen, and M. T. Vlachaki, "Role of ovarian transposition based on the dosimetric effects of craniospinal irradiation (CSI) on the ovaries: a case report," International Journal of Radiation Oncology Biology Physics, vol. 66, no. 3, supplement, p. S708, 2006.

[22] M. Bidzinski, B. Lemieszczuk, and J. Zielinski, "Evaluation of the hormonal function and features of the ultrasound picture of transposed ovary in cervical cancer patients after surgery and pelvic irradiation," European Journal of Gynaecological Oncology, vol. 14, supplement, pp. 77-80, 1993.

[23] B. Anderson, J. LaPolla, D. Turner, G. Chapman, and R. Buller, "Ovarian transposition in cervical cancer," Gynecologic Oncology, vol. 49, no. 2, pp. 206-214, 1993.

[24] K. G. Huang, C. L. Lee, C. S. Tsai, C. M. Han, and L. L. Hwang, "A new approach for laparoscopic ovarian transposition before pelvic irradiation," Gynecologic Oncology, vol. 105, no. 1, pp. 234-237, 2007.

[25] S. K. Chambers, J. T. Chambers, R. Kier, and R. E. Peschel, "Sequelae of lateral ovarian transposition in irradiated cervical cancer patients," International Journal of Radiation Oncology Biology Physics, vol. 20, no. 6, pp. 1305-1308, 1991.

[26] M. Kwik, A. O’Neill, Y. Hamani, M. Chapman, and D. Chou, "Laparoscopic ovarian transposition with potential preservation of natural fertility," Journal of Minimally Invasive Gynecology, vol. 17, no. 4, pp. 411-412, 2010.

[27] T. Tulandi and S. Al-Took, "Laparoscopic ovarian suspension before irradiation," Fertility and Sterility, vol. 70, no. 2, pp. 381383, 1998.

[28] K. Fujiwara, H. Mohri, T. Yoshida, H. Yamauchi, and I. Kohno, "Subcutaneous transposition of the ovary following hysterectomy," International Journal of Gynecology and Obstetrics, vol. 58, no. 2, pp. 223-228, 1997.

[29] D. D. Feeney, D. H. Moore, K. Y. Look, F. B. Stehman, and G. P. Sutton, "The fate of the ovaries after radical hysterectomy and ovarian transposition," Gynecologic Oncology, vol. 56, no. 1, pp. 3-7, 1995.

[30] K. B. Clough, F. Goffinet, A. Labib et al., "Laparoscopic unilateral ovarian transposition prior to irradiation: prospective study of 20 cases," Cancer, vol. 77, no. 12, pp. 2638-2645, 1996. 
[31] P. Morice, L. Juncker, A. Rey, J. El-Hassan, C. Haie-Meder, and D. Castaigne, "Ovarian transposition for patients with cervical carcinoma treated by radiosurgical combination," Fertility and Sterility, vol. 74, no. 4, pp. 743-748, 2000.

[32] P. Morice, C. Haie-Meder, P. Pautier, C. Lhomme, and D. Castaigne, "Ovarian metastasis on transposed ovary in patients treated for squamous cell carcinoma of the uterine cervix: report of two cases and surgical implications," Gynecologic Oncology, vol. 83, no. 3, pp. 605-607, 2001.

[33] P. Morice, D. Castaigne, C. Haie-Meder et al., "Laparoscopic ovarian transposition for pelvic malignancies: indications and functional outcomes," Fertility and Sterility, vol. 70, no. 5, pp. 956-960, 1998.

[34] M. A. van Eijkeren, I. van der Wijk, S. Y. El Sharouni, and A. P. M. Heintz, "Benefits and side effects of lateral ovarian transposition (LOT) performed during radical hysterectomy and pelvic lymphadenectomy for early stage cervical cancer," International Journal of Gynecological Cancer, vol. 9, no. 5, pp. 396-400, 1999.

[35] O. Picone, J. S. Aucouturier, A. Louboutin, Y. Coscas, and E. Camus, "Abdominal wall metastasis of a cervical adenocarcinoma at the laparoscopic trocar insertion site after ovarian transposition: case report and review of the literature," Gynecologic Oncology, vol. 90, no. 2, pp. 446-449, 2003.

[36] F. B. Stehman, S. Ali, H. M. Keys et al., "Radiation therapy with or without weekly cisplatin for bulky stage $1 \mathrm{~B}$ cervical carcinoma: follow-up of a gynecologic oncology group trial," The American Journal of Obstetrics and Gynecology, vol. 197, no. 5, pp. 503.el-503.e6, 2007.

[37] M. Candelaria, A. Garcia-Arias, L. Cetina, and A. DueñasGonzalez, "Radiosensitizers in cervical cancer. Cisplatin and beyond," Radiation Oncology, vol. 1, no. 1, article 15, 2006.

[38] Y. Kobayashi, F. Akiyama, and K. Hasumi, "A case of successful pregnancy after treatment of invasive cervical cancer with systemic chemotherapy and conization," Gynecologic Oncology, vol. 100, no. 1, pp. 213-215, 2006.

[39] A. Maneo, S. Chiari, C. Bonazzi, and C. Mangioni, "Neoadjuvant chemotherapy and conservative surgery for stage IB1 cervical cancer," Gynecologic Oncology, vol. 111, no. 3, pp. 438443, 2008.

[40] J. Tangir, D. Zelterman, W. Ma, and P. E. Schwartz, "Reproductive function after conservative surgery and chemotherapy for malignant germ cell tumors of the ovary," Obstetrics and Gynecology, vol. 101, no. 2, pp. 251-257, 2003.

[41] T. Seshadri, M. J. Hourigan, M. Wolf, P. N. Mollee, and J. F. Seymour, "The effect of the Hyper-CVAD chemotherapy regimen on fertility and ovarian function," Leukemia Research, vol. 30, no. 4, pp. 483-485, 2006.

[42] H. Kang, T. J. Kim, W. Y. Kim et al., "Outcome and reproductive function after cumulative high-dose combination chemotherapy with bleomycin, etoposide and cisplatin (BEP) for patients with ovarian endodermal sinus tumor," Gynecologic Oncology, vol. 111, no. 1, pp. 106-110, 2008.

[43] C. Díaz-García, S. N. Akhi, A. Wallin, A. Pellicer, and M. Brännström, "First report on fertility after allogeneic uterus transplantation," Acta Obstetricia et Gynecologica Scandinavica, vol. 89, no. 11, pp. 1491-1494, 2010.

[44] A. Hanafy, C. Diaz-Garcia, M. Olausson, and M. Brännström, "Uterine transplantation: one human case followed by a decade of experimental research in animal models," Australian and New Zealand Journal of Obstetrics and Gynaecology, vol. 51, no. 3, pp. 199-203, 2011.
[45] I. Kisu, K. Banno, M. Mihara, T. Iida, and Y. Yoshimura, "Current status of surrogacy in Japan and uterine transplantation research," European Journal of Obstetrics Gynecology and Reproductive Biology, vol. 158, no. 2, pp. 135-140, 2011.

[46] A. Lefkowitz, M. Edwards, and J. Balayla, “The montreal criteria for the ethical feasibility of uterine transplantation," Transplant International, vol. 25, no. 4, pp. 439-447, 2012.

[47] P. L. Giacalone, F. Laffargue, P. Bénos, H. Dechaud, and B. Hédon, "Successful in vitro fertilization-surrogate pregnancy in a patient with ovarian transposition who had undergone chemotherapy and pelvic irradiation," Fertility and Sterility, vol. 76, no. 2, pp. 388-389, 2001.

[48] D. H. Barad, A. Weghofer, and N. Gleicher, "Comparing antiMüllerian hormone (AMH) and follicle-stimulating hormone (FSH) as predictors of ovarian function," Fertility and Sterility, vol. 91, no. 4, pp. 1553-1555, 2009.

[49] J. Kwee, R. Schats, J. McDonnell, A. Themmen, F. de Jong, and C. Lambalk, "Evaluation of anti-Müllerian hormone as a test for the prediction of ovarian reserve," Fertility and Sterility, vol. 90, no. 3, pp. 737-743, 2008.

[50] I. A. J. van Rooij, F. J. M. Broekmans, E. R. T. Velde et al., "Serum anti-Müllerian hormone levels: a novel measure of ovarian reserve," Human Reproduction, vol. 17, no. 12, pp. 3065-3071, 2002. 


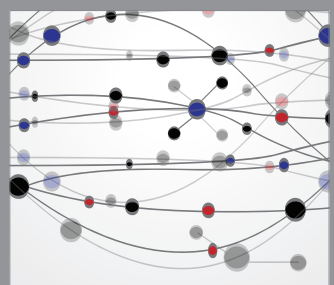

The Scientific World Journal
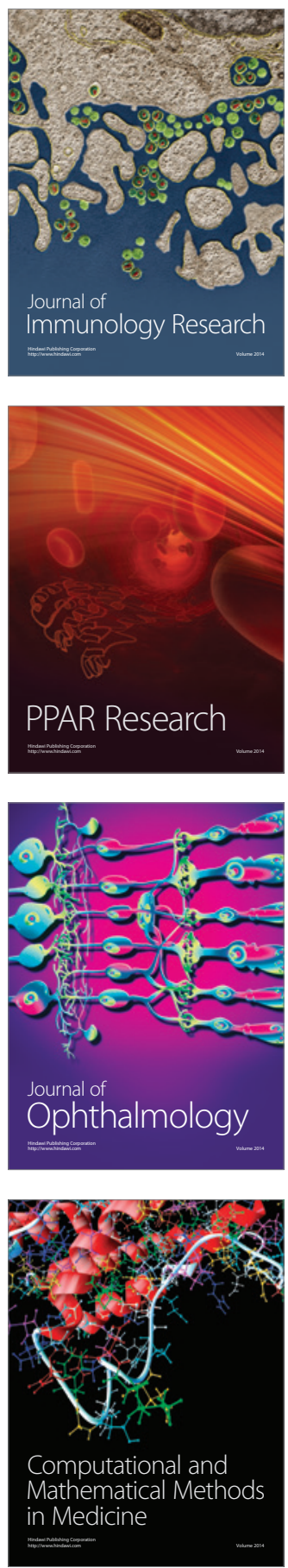

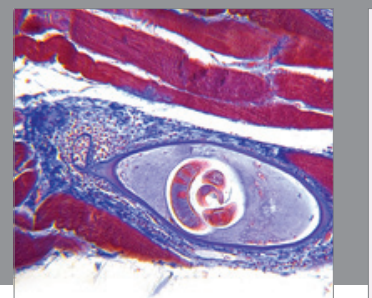

Gastroenterology

Research and Practice
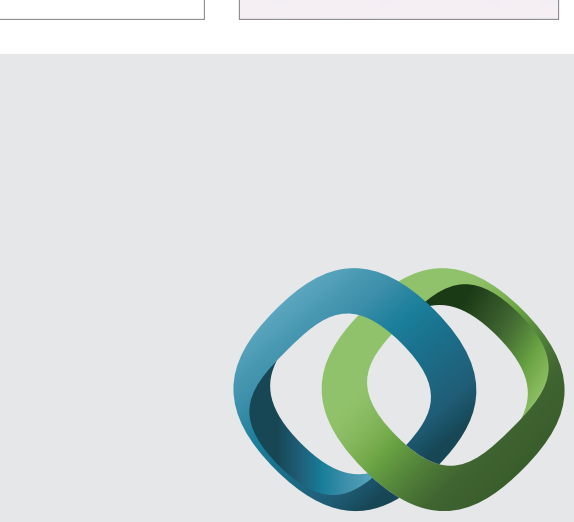

\section{Hindawi}

Submit your manuscripts at

http://www.hindawi.com
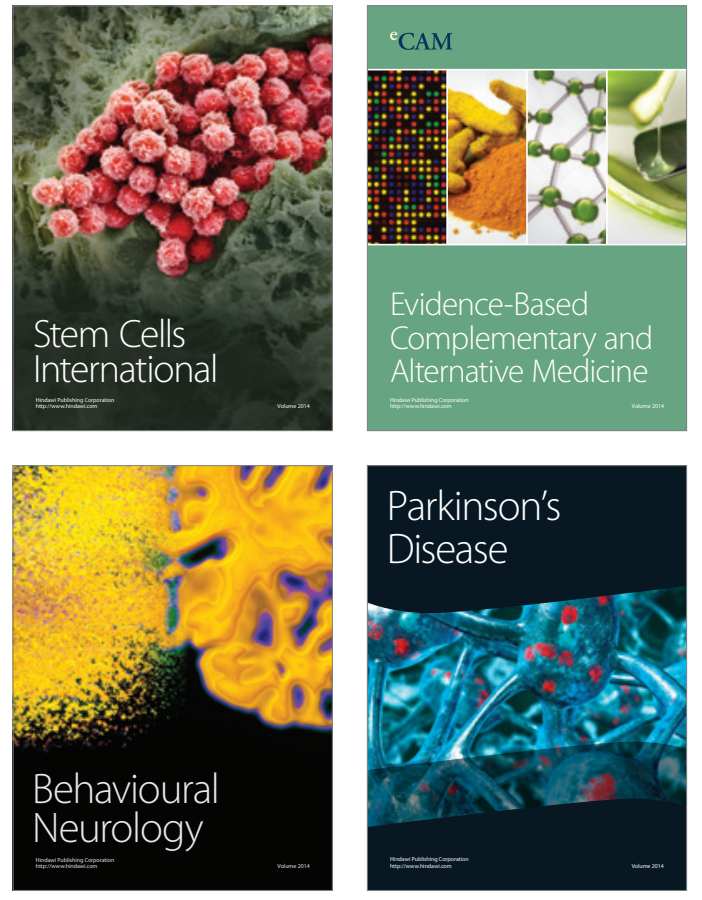
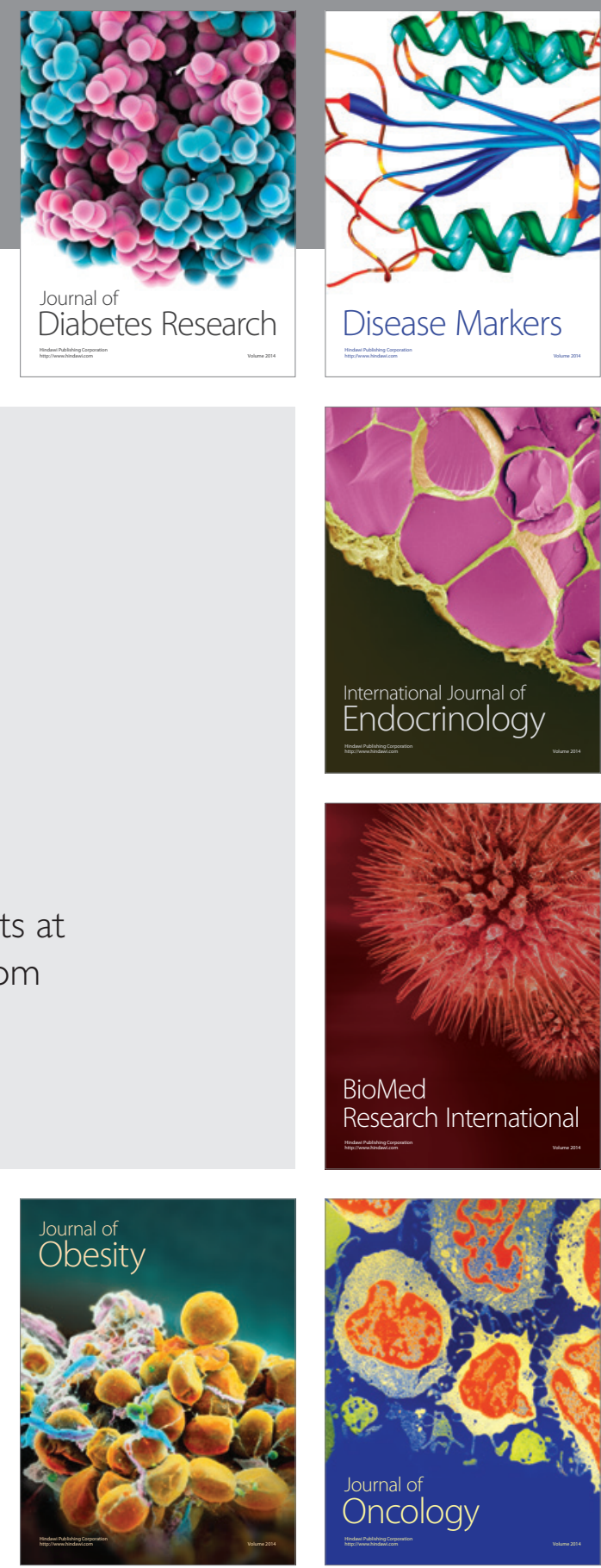

Disease Markers
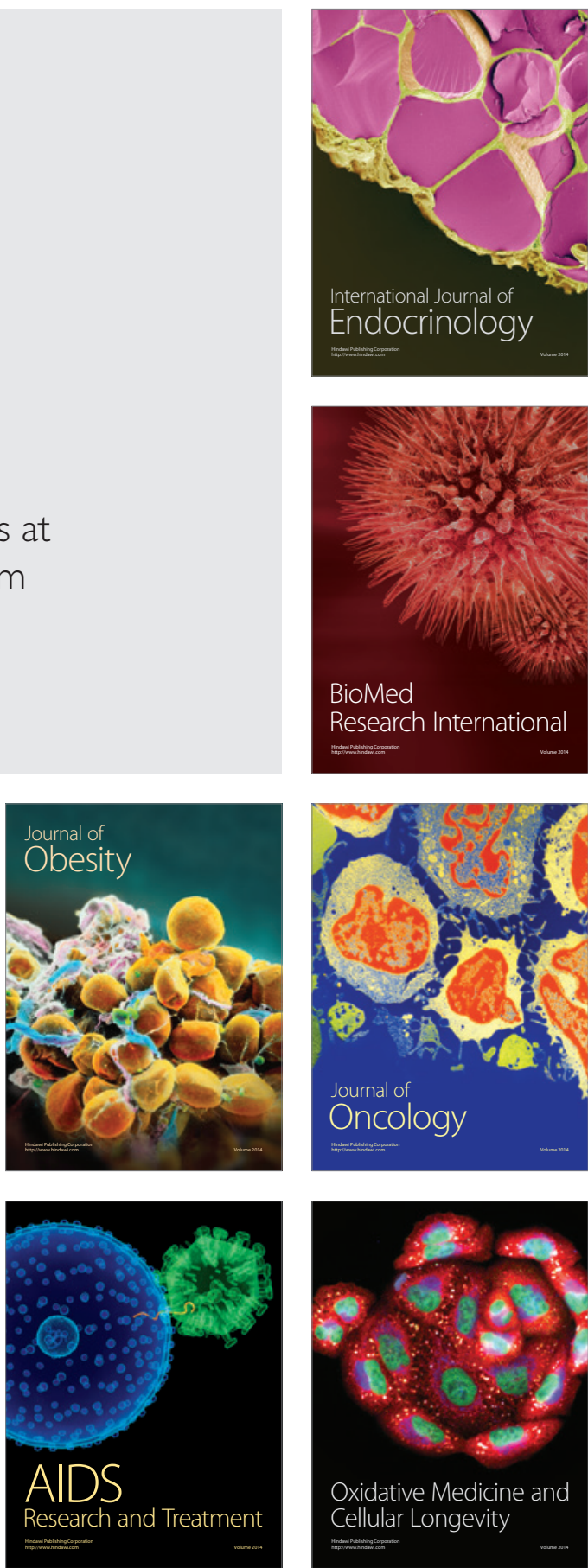